\title{
Turkey and the IMF: A case study in the political economy of policy implementation
}

\author{
Ozlem Arpac • Graham Bird
}

Received: 30 September 2008 /Revised: 14 December 2008 /Accepted: 15 December 2008 /

Published online: 24 January 2009

(C) Springer Science + Business Media, LLC 2009

\begin{abstract}
Research into IMF program implementation has usually taken the form of large sample regression analyses. A more detailed explanation is offered in this paper through a case study of program implementation in Turkey between 1999 and 2004. Our research is based on a series of in-depth interviews with policy makers, program negotiators, bureaucrats, interest groups and IMF personnel. Our results reinforce hypotheses that emerge from the theory of implementation and the large sample econometric work, but they also offer new and enhanced explanations. Program implementation depends on a range of factors which interact with one another. These include domestic political economy factors, such as the importance of special interest groups, political cohesiveness and program ownership by the government and the IMF, but also other idiosyncratic factors such as, in the case of Turkey, the existence of a crisis, the desire to join the EU and the role of influential technocrats. Our research has implications for the design of IMF programs.
\end{abstract}

Keywords IMF programs · Conditionality · Implementation · Turkey ·

Political economy of implementation

JEL Classification $\mathrm{F} 33 \cdot \mathrm{E} 61 \cdot \mathrm{E} 65$

\section{Introduction}

Increasing attention has been paid to the implementation of IMF programs rather than just the conditionality they embody. Part of this research has been theoretical and part of it has been empirical. The theoretical research has focused on the role of special interest groups or veto players, arguing that they may be able to disrupt the implementation of policy (see, for example, Drazen 2002, but also Grossman and

O. Arpac $\cdot$ G. Bird $(\bowtie)$

Surrey Centre for International Economic Studies, University of Surrey, Guildford,

GU2 7XH Surrey, UK

e-mail: g.bird@surrey.ac.uk 
Helpman 2001; Khan and Sharma 2000; Mayer and Mourmouras 2004, 2008, and Tsebelis 2001a and 2001b). The empirical research has taken the form of large sample regression analyses (see, for example, Ivanova et al. 2003; Dreher 2003; Joyce 2006, and Arpac et al. 2008). It has revealed mixed results although it has identified various domestic political economy factors as being generally significant determinants of implementation, alongside economic characteristics such as openness.

A shortcoming of the research up until now, however, is that it has been rather broad and non-specific in its approach. The empirical work has also been constrained by the availability of data. The implication of this is that while an indication of the factors affecting implementation has been assembled, a more detailed explanation is still missing. Putting together such an explanation requires a different methodological approach that is based on in-depth structured case studies. Over time it will be by amassing these that a more rounded and fuller understanding of implementation will be achieved. However, it is important that the case study methodology is informed by the relevant theory and by existing large sample research, so that it is seen as a complementary rather than a competing methodology.

This paper takes a step in this direction by reporting on a detailed examination of the implementation of IMF programs in Turkey over the period from 1980 to 2004, but with particular attention being paid to 1999-2004. Turkey is chosen because of its long history of involvement with the IMF (see Table 1) and the diverse pattern of

Table 1 Arrangements with the IMF: 1948-2005

\begin{tabular}{|c|c|c|c|c|c|c|c|}
\hline & Date & Cancellation & $\begin{array}{l}\text { Number } \\
\text { of Months }\end{array}$ & $\begin{array}{l}\text { Amount } \\
\text { (SDR Millions) }\end{array}$ & $\begin{array}{l}\text { Disbursed } \\
\text { (SDR Millions) }\end{array}$ & $\begin{array}{l}\text { Disbursement } \\
\text { rate }(\%)\end{array}$ & $\begin{array}{l}\text { Arrangement } \\
\text { type }\end{array}$ \\
\hline & 1948 & & 12 & 5 & 5 & 100 & Gold tranche \\
\hline & 1953 & & 12 & 10 & 10 & 100 & Gold tranche \\
\hline & 1954 & & 12 & 20 & 20 & 100 & Gold tranche \\
\hline & 1957 & & 12 & 13.5 & 13.5 & 100 & Gold tranche \\
\hline & 1958 & & 12 & 25 & 25 & 100 & Gold tranche \\
\hline 1 & 1961 & & 12 & 37.5 & 16 & 42.6 & Stand-By \\
\hline 2 & 1962 & & 9 & 31 & 15 & 48.4 & Stand-By \\
\hline 3 & 1963 & & 11 & 21.5 & 21.5 & 100 & Stand-By \\
\hline 4 & 1964 & & 11 & 21.5 & 19 & 88.4 & Stand-By \\
\hline 5 & 1965 & & 12 & 21.5 & 0 & 0 & Stand-By \\
\hline 6 & 1966 & & 12 & 21.5 & 21.5 & 100 & Stand-By \\
\hline 7 & 1967 & & 11 & 27 & 27 & 100 & Stand-By \\
\hline 8 & 1968 & & 9 & 27 & 27 & 100 & Stand-By \\
\hline 9 & 1969 & & 12 & 27 & 10 & 37 & Stand-By \\
\hline 10 & 1970 & & 12 & 90 & 90 & 100 & Stand-By \\
\hline 11 & 1978 & 1979 & 24 & 300 & 90 & 3 & Stand-By \\
\hline 12 & 1979 & 1980 & 12 & 250 & 230 & 92 & Stand-By \\
\hline 13 & 1980 & & 36 & 1,250 & 1,250 & 100 & Stand-By \\
\hline 14 & 1983 & & 12 & 225 & 56.3 & 25 & Stand-By \\
\hline 15 & 1984 & 1984 & 12 & 225 & 169 & 75 & Stand-By \\
\hline 16 & 1994 & 1996 & 14 & 610 & 460 & 75 & Stand-By \\
\hline 17 & 1999 & & 36 & 1,5038 & 11,738 & 78 & $\begin{array}{l}\text { Stand-By } \\
\text { and SRF }\end{array}$ \\
\hline 18 & 2002 & & 36 & 12,821 & 11,914 & 92.9 & Stand-By \\
\hline 19 & 2005 & & 36 & 6,662 & Continuing & & Stand-By \\
\hline
\end{tabular}

Source: IMF Annual Reports (2000-2004), Ekzen (1980), Egilmez (2005) 
implementation that has been exhibited. Our methodological approach is one not often used by economists, although frequently used by other social scientists. Having formulated some hypotheses on the basis of the extant theoretical and empirical research, and having formed views from examining the available statistical evidence and the literature, we undertook a series of lengthy interviews with those involved in the programs (a schedule of interview participants is provided in Appendix A). These included key Turkish politicians, bureaucrats, the leaders of special interest groups and relevant IMF personnel including mission chiefs and resident representatives. We also consulted academic experts on Turkey, in particular to check their perception of the validity of the conclusions we drew and to try and ensure that we had not overlooked anything that was important.

Although our approach is essentially qualitative, we do attempt to offer some quantification of the importance of the individual determinants that our research identifies. We also attempt to anticipate the criticism that case studies are limited in their usefulness because the results that emerge from them cannot be generalized. We do this by relating our results to the existing large sample cross country regression research.

The paper is organized in the following way. Section 2 is a broad summary of the large sample research on program implementation. In Section 3, we explore Turkey's record in terms of the incidence of IMF programs, and the record of economic policy and performance from 1980 to 2004. This examination enables us to offer some commentary on what seemed to be going on. It provides the contextual framework for what follows. Section 4 summarizes the views of those who we interviewed. However, rather than simply recording what they had to say, we arrange our discussion around some of the key factors that have been identified by the theoretical research into implementation and by the large sample regression analyses. Section 5 presents a quantitative summary of the qualitative views, and also examines the extent to which the findings may be generalized across a sample of other countries. It also investigates the policy implications of our findings. Finally, Section 6 offers some concluding remarks.

\section{Large Sample Evidence on Program Implementation}

A mixed picture emerges from the literature assessing the determinants of IMF program implementation. A range of economic and political factors has been included in estimations as suggested by the theoretical studies of implementation. We do not review the literature in detail here since we have carried out this exercise elsewhere (see Arpac et al. 2008). However in Table 2 we present a brief summary of the major empirical findings that emerge from the existing literature and it is upon these that the current paper builds. While, most studies of program implementation concur that political factors are important in influencing implementation, there is a disagreement about the precise nature of the political influence. Arpac et al. (2008) find that program interruptions are associated with the strength of domestic interest groups using the World Bank's veto players measure, while conventionally used measures of special interest groups generate insignificant results (Dreher 2003; Joyce 2006). The political cohesion variable is found to be significant by Ivanova et al. (2003) but not by Joyce (2006). Also, Ivanova et al. (2003), Joyce (2006) and Dreher (2003) find that the degree of democracy is statistically significant. 


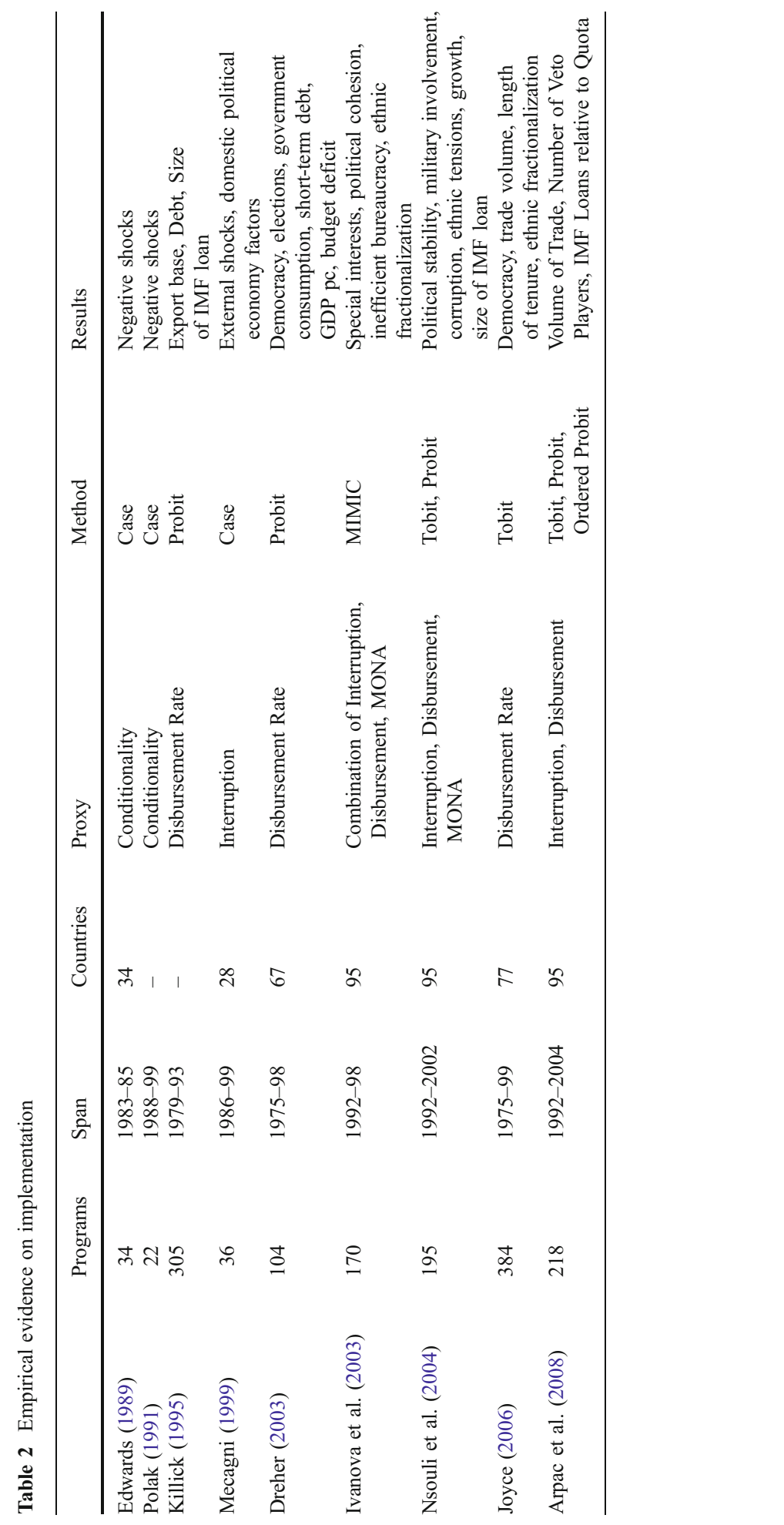


Turning to the macroeconomic dimension of implementation, earlier studies of implementation attribute poor compliance to unfavorable initial and external macroeconomic conditions (Edwards 1989; Polak 1991; Killick 1995; Mecagni 1999). More recent studies by Joyce (2006) and Arpac et al. (2008) find that program implementation depends on the openness of economies as proxied by the volume of trade. ${ }^{1}$ The econometric evidence also suggests that the IMF can affect implementation through the amount of financial assistance it stands ready to provide (Killick 1995; Nsouli et al. 2004; Arpac et al. 2008).

\section{Policy, Performance and Programs: Turkey and the IMF}

Having had a sequence of programs with the IMF since 1964 (see Table 1), Turkey began to implement what might be seen as neo-liberalist reforms under the auspices of the IMF and the World Bank in 1980. Eliminating current account payments imbalances and reducing the rate of inflation were, however, the immediate targets of the IMF programs. The principal policy instruments for achieving these targets were monetary contraction, exchange rate devaluation and the liberalization of key prices, such as interest rates on bank deposits. IMF programs sought to lay the foundations for sustained economic growth by reforming the financial sector and liberalizing foreign trade (Onis 1986; Onis and Ozmucur 1988). ${ }^{2}$

Although in the early 1980s there was a reasonably close correspondence between the views of the IMF and those of Turkish policy makers as to what reforms were necessary, improving economic performance meant that the Turkish authorities no longer saw the need for IMF programs after 1984. However, by the end of the 1980s the momentum for reform was declining. Distributional pressures that had been largely repressed during the early 1980 s re-asserted themselves and were manifested in larger fiscal deficits. Accompanied by high real rates of interest, these were financed by capital inflows which were facilitated by a liberalized capital account and the convertibility of the Turkish lira. By the beginning of the 1990s, Turkey was adopting a vulnerable path of debt-led economic growth.

Heavy borrowing by the government resulted in commercial banks holding short positions in foreign currencies. In order to finance their purchases of government bonds, the banks borrowed short term from international capital markets pledging the bonds as collateral. With inadequate risk management, the banking sector became progressively more exposed. However, in the context of a highly fragmented political system, successive coalition governments lacked either the incentives or the capacity to undertake fiscal reform and to regulate the banking sector. Instead,

\footnotetext{
${ }^{1}$ Openness may be affected by both structural factors such as country size and policy related measures such as tariffs. Countries with high tariffs may find it more difficult to implement the fiscal component of IMF programs, as they rely on this form of tax revenue. This makes it problematic to disentangle the connection between trade policy and implementation, as there are various measures of outward orientation, but they are not correlated (Pritchett 1996). Therefore, the volume of trade proxy is generally adopted in the literature.

${ }^{2}$ A comprehensive analysis of Turkey's development experience is beyond the scope of this paper. There is a vast literature on the economic development of Turkey. See, among others, Boratav (2003) and Yeldan (2001).
} 
frequently elected on a populist agenda, they allowed government expenditure to rise and fiscal and current account deficits to widen. The situation was only sustainable for as long as foreign capital flowed in. There was, in short, a financial crisis waiting to happen. ${ }^{3}$

It arrived in early 1994 when Standard and Poor's and Moody's reduced Turkey's credit rating. As the lira's value depreciated, the government was driven to the IMF for assistance. A fourteen month Stand-By Arrangement, signed in April 1994, was built around a large, front-end loaded fiscal correction combined with a tighter stance on monetary policy. Initially the program's implementation was satisfactory, and it was extended. But in September, 1995, the governing coalition collapsed and elections were called. In the resulting political turmoil the IMF program went off course and the final review of it was never completed. The underlying macroeconomic disequilibria continued to worsen and the fragmented political system, incorporating a powerful populist element, did not allow fundamental economic reform to be carried through. Towards the end of the 1990s, however, the economic costs of populism and the sustainability of contemporary policies were being reassessed by policy makers.

In July, 1998, a Staff Monitoring Program had been agreed with the IMF and this was followed, after the general election in April, 1999, by a Stand-By Arrangement in December, 1999. The new coalition government incorporating the left nationalist Democratic Left Party (DSP) under the leadership of Bulent Ecevit, the radical nationalist Nationalist Action Party (MHP) under Devlet Bahceli and the right of centre Motherland Party under Mesut Yilmaz, seemed committed to implementing a far-reaching program of disinflation and structural reform involving taxation reform, privatization, banking regulation and the phasing out of agricultural price support.

The program was ambitious, aiming to bring inflation down to 25 percent by the end of 2000, 12 percent by the end of 2001 and to 7 percent by the end of 2002 . A tight fiscal policy, an incomes policy in line with targeted inflation, and monetary policy formulated in line with decelerating inflation, formed the basis of the program. It also incorporated a crawling exchange rate regime. This envisaged a gradual and smooth transition to a flexible exchange rate after the first critical 18 months.

The Turkish lira was allowed to depreciate gradually until 2003, against a currency basket made up of the US dollar and the euro. In essence, Turkey sought to implement a system akin to a currency board, but in the context of a currency that was depreciating in a pre-announced fashion.

The program started well amidst considerable optimism for success. The endorsement of Turkey's candidacy for full membership of the European Union at the Helsinki summit in December, 1999, at the same time as the IMF agreement was launched, provided a powerful incentive for undertaking both political and economic reforms. Throughout 2000, exchange rate depreciation followed the envisaged schedule and the Central Bank successfully controlled the expansion of the monetary base by constraining its net domestic asset position. During 2000, the quantitative performance criteria were met. However, whilst the government appeared to display an initial commitment to the fiscal component of the program, this commitment

\footnotetext{
${ }^{3}$ For a detailed account of economic crises in Turkey, see Onis and Rubin (2003) and Akyuz and Boratav (2003).
} 
ultimately proved to be less than total. In spite of agreeing not to do so, the government progressively relied on 'extra budgetary' ways of financing government expenditure which were free from parliamentary supervision and control. Although the coalition government had initially displayed a unified front, it soon became apparent that it lacked the necessary cohesion and commitment to maintain the reform process. Serious conflicts arose during the year between the Nationalist Action Party and its partners over key aspects of structural reform. In particular, the Nationalist Action Party opposed reducing agricultural subsidies on the grounds that it would have undesirable effects on income distribution, and, in particular, on the rural poor from whom the party gained much of its support. It also opposed the sale of state assets in telecommunications on the grounds of the strategic importance of the industry.

The formation of the Bank Regulation and Supervision Authority (BRSA) also proved to be an area of difficulty. The Board of the BSRA was supposed to be named by the end of March 2000 in order for it to become fully operational by August and to comply with one of the IMF's structural benchmarks. However, by the end of August, the members had only just been appointed. Furthermore, the ability of the Authority to play a constructive regulatory role was severely hampered by the resistance of private banking lobbies. Bank regulation also faced resistance from politicians and some policy makers who perceived private banks as an important source of financing for the fiscal deficit and public banks as a modality for building up and sustaining electoral support. As a consequence the banking legislation was initially watered down.

By the autumn of 2000, market confidence in the program was seriously waning. Structural benchmarks were being missed and the government appeared to be back tracking on structural reform. In the absence of strong political endorsement, it was left to the governor of the Central Bank to defend the program. The government displayed little ownership of it. With a boom in consumption fostered by low interest rates and an increasing current account deficit, Turkey became vulnerable to a sudden capital outflow, especially as international capital markets became more risk averse in the aftermath of the East Asian crisis in 1997/98.

Confidence was further undermined in September 2000 when some former bank owners were accused of 'organized crime' and in November 2000 when the BRSA encouraged banks to reduce their open positions by the end of the year. ${ }^{4} \mathrm{~A}$ tightening liquidity situation led to the failure of the medium sized Demirbank and to rising interest rates. Fear of a liquidity crisis then encouraged the Central Bank to relax monetary policy which in turn put pressure on the exchange rate as capital rapidly flowed out of the country. On the last day of November the Central Bank declared that it would respect the NDA limits in an attempt to staunch the decline in reserves, and in the days that followed overnight market interest rates reached over 2,000 percent. However, the capital outflow only abated when the IMF package was announced at the end of December. The Demirbank was taken over by the BSRA and the government issued credit guarantees to underwrite the banks. Supplemented with resources from the Supplemental Reserve Facility, the IMF provided SDR

\footnotetext{
${ }^{4}$ For detailed analysis of the problems associated with open positions and the links to the crises, see Alper (2001).
} 
15 billion of financial assistance in total. This allowed reserves to be replenished and calmed markets for a while. But market confidence remained low, and Turkey remained vulnerable to a further economic and financial crisis.

On February 19, 2001, Prime Minister Ecevit disclosed that he had had a serious dispute with President Sezer during a meeting of the National Security Council, and that, as a result, the country was in a 'political crisis'. The dispute related to the President's concerns about weak bank supervision and, as he saw it, the Government's inadequate measures against corruption among public officials. There followed a major speculative attack on the lira and another liquidity squeeze. However, unlike the November crisis, this time the Central Bank refused to act as a lender of last resort. Overnight rates rose to more than 4,000 percent. When, in February, two public banks announced that they were unable to meet their lira obligations to other banks, the interbank system broke down. On February 23, the government floated the lira. The experiment with exchange rate based stabilization had come to an end.

The February 2001 crisis constituted the deepest economic crisis ever faced by Turkey. Moreover, it affected all sectors of society. It demonstrated the shortcomings of patronage networks, and further eroded the general public's trust in politicians and the political system. ${ }^{5}$ The Central Bank governor and the Undersecretary of the Treasury resigned, and the government appointed Kemal Dervis from the World Bank as Minister of Economic Affairs, giving him the responsibility of defusing the crisis. Dervis was originally offered the position of Central Bank governor, but argued that "only a minister of economic affairs with strong co-ordinating powers would have any chance of succeeding." (Dervis 2005, p. 86).

As well as holding his Treasury position, Dervis was given the responsibilities of co-ordinating the Central Bank and the BSRA, and of negotiating with the IMF and World Bank. But he was not given any authority over key ministries since each coalition party wanted to retain some control over economic management.

Dervis formed a core team including the new governor of the Central Bank, Sureyya Serdengecti, the Undersecretary of the Treasury, Faik Oztrak, and the new head of the BRSA, Engin Akcakoca. The team prepared a new national program based on strict fiscal control and front-end loaded structural reforms. On May 15, Dervis submitted a new 'Letter of Intent' to the IMF and announced the 'Strong Economy Program' aimed at transforming 'the old ways of policy making' (Letter of Intent, May 2001, p. 1).

The same government that had overseen two major economic crises now played an instrumental role in passing a record number of laws. In less than a year nineteen laws or regulations relating to structural reform were passed. The most important of these granted independence to the Central Bank, reformed the banking system, overhauled agricultural policy (moving from price support to income support) and sought to control public debt. They also covered the civil aviation, telecommunications, tobacco and sugar industries as well as the regulation of public procurement.

\footnotetext{
${ }^{5}$ For contrasting interpretations of the reasons underlying the crises of 2000 and 2001, see Akyuz and Boratav (2003) and Cizre and Yeldan (2005), which place the blame on the IMF for failing to prevent the crisis in the context of the ongoing programs. Others such as Onis and Rubin (2003), take into account the domestic political constraints and poor government ownership.
} 
Nevertheless, resistance to reform had not disappeared altogether. Major clashes occurred between Dervis and the Nationalist Action Party, key members of the coalition, over a number of issues including telecommunications, where the Nationalist Action Party wanted to maintain control by selecting four members of the seven person board. In particular the clash between Dervis and the Transport Minister, Enis Oksuz, led to delay in the release of the IMF loan. However, in postcrisis conditions, the views of the IMF proved decisive in overcoming resistance and the episode ended with the resignation of Oksuz. The IMF's First Deputy Managing Director, Stanley Fischer, observed at the time that:

"Turkey has already made impressive progress in implementing this very ambitious program: it has undertaken important banking sector and other structural reforms, continued strong fiscal adjustment despite difficult economic circumstances and carried out an extensive legislative agenda."

But the very success of the program bred further difficulties and, in August 2002, Dervis himself resigned, sensing increasing strains within the coalition government.

The November 2002 elections saw members of the coalition government being penalized by the electorate for the economic crisis. This paved the way for the emergence of a new political party with Islamist roots but a moderate outlook, the Justice and Development Party (AKP), which went on to take centre stage in Turkish politics. As a single party majority government, and contrary to some concerns that it would indulge in a new round of populist expansion, deviating from the IMF program, the AKP adopted a strong reformist stance. Capitalizing on its broad-based political support, the new government was able to continue to implement the Strong Economy Program. Tight fiscal discipline was accomplished. Inflation was not only stabilized in single digits, but this was achieved within the context of economic growth, which in turn allowed the debt-GNP ratio to fall.

\section{Interpreting the Record on Implementation: The Views of Participants}

In this section, we examine Turkey's relationship with the IMF over the period 1999-2004 in more detail, with a view to both testing the theories of policy implementation and examining the extent to which the qualitative evidence is consistent with the findings from large sample regression analyses. A time line of key events is provided in Appendix B, and Table 3 provides a summary of the main economic indicators in Turkey over the period. Our methodology was to undertake a series of structured interviews with those involved in the process, including leading domestic politicians, bureaucrats and other domestic policy makers, those representing special interest groups and IMF officials involved in the programs. The structured interviews included questions on participants' views on program negotiation and implementation with a particular emphasis being placed on factors suggested by the literature, such as macroeconomic conditions, domestic policy and external constraints. In addition, numerous additional factors, which interacted with the above variables, were discovered through the interviews.

We attempted, as far as was possible, to cover a reasonably representative and balanced sample of participants. The purpose was to assemble a richer and more 





nuanced explanation of implementation than is provided by large sample studies. However, in order to create an analytical framework for our discussion, and as noted above, we based our investigation on the factors that are suggested both by theory and by cross country regression analysis. In Appendix A we summarize the schedule of interviews we undertook.

\subsection{Special Interest Groups}

Political parties in Turkey have often acted as patronage networks serving narrowly based sectional interests. The power of special interest groups therefore constrained policy implementation. For instance, Carlo Cottarelli, IMF mission chief to Turkey during the 1999 program, attributed delays in banking reform to the existence of a strong banking lobby that was opposed to it. He points out that,

"The pressure was on the government not to do anything before 2001. The tackling of problems in the banking system was delayed and delayed, clearly because of the banking sector's resistance to reforms and because of the difficulty the government had in acknowledging that public sector money was to be used to bail out the failing banks."

According to Sumer Oral, the former Minister of Finance, the government's role had to balance the demands of special interest groups with those of the IMF. Economic circumstances determined where the balance lay. During the autumn of 2000 the balance was in favor of the interest groups and there were delays in implementing IMF-backed policies. After the February 2001 crisis, the ability of special interest groups to slow down the pace of reform was significantly diminished. Indeed in severe crisis conditions they themselves stood to lose.

As Kemal Dervis, Minister of Economic Affairs, points out,

"The industrialists and the bankers would have had great losses had the economy sunk totally. People who invested in the country were hoping that the program would offer an exit. Some of them were against some parts of the program. For instance, businessmen were initially against the free float. But there was overall support."

Faik Oztrak, who was Undersecretary of the Treasury, agreed. According to him, the economic crisis forced special interest groups to back the government. It was only when the program started to show good results that they began to reaffirm their sectional interests.

Dervis observed that in the crisis, there was little option other than to implement the program favored by the IMF. The single exception, according to him, was organized labor; a fear of social upheaval led the government to resist the IMF's preferred wages policy.

In the absence of a severe crisis things were different. Juha Kahkonen, who took over from Cottarelli as IMF mission chief, attributed slippages in structural reform to the "pressure of the special interest groups" quoting the delays in privatization and banking sector reform as examples.

Hugh Bredenkamp, the IMF Resident Representative to Turkey, argued that even the AKP government succumbed to special interest groups to a degree. By raising 
tax rates in one sector and reducing them in another the government tried to maintain support from key constituencies, whereas the IMF favored a broad based tax regime.

\subsection{Weak Institutions}

There was general agreement amongst those we interviewed that poor implementation was associated with weak institutions that were open to political influence. As both Oral and Kahkonen stressed, weak institutions made programs vulnerable to slippage. One difficulty was, of course, that institutional reform was itself a part of the programs. It was the severe crisis in 2001 that provided the needed impetus to institutional reform.

Perhaps the most striking institutional reform related to the BSRA. Although set up in 1999, prior to the onset of the crisis, it was initially largely ineffective. Engin Akcakoca, who became its head, explained the demands of the banking sector as follows,

"The banking sector did not want harsh regulation, and they wanted less money leaving their pockets. There was a big gap between what the sector wanted and what the Banking Agency and the IMF wanted."

However, in the aftermath of the February 2001 crisis, the power and autonomy of the BSRA increased significantly, even though politicians remained rather reluctant to cede control to it. As Akcakoca observed,

"The government was not used to independent agencies. They wanted to solve problems on their own, out of habit. The banking agency had to warn them against this and, of course, there were reactions from the sector. But once the bankrupted banks were taken out of the system and the remaining ones got stronger, they saw that what had been done was good."

\subsection{Political Cohesion and Ownership}

For much of the time covered by our study, the coalition government exhibited severe divisions which made it difficult to implement any one overall strategy. As Oral argues,

"There was a government coalition with three parties with quite different perspectives on how the economy should be run. This sort of government could not execute a single-handed economic implementation."

While, in December 1999, the coalition government had been under significant external pressure to put in place a Fund-backed program, not all coalition partners shared a lasting commitment to reform. Cottarelli observed that the support for the program gradually lapsed during 2000, noting that,

"At the beginning, fiscal tightening was in place and a series of reforms were implemented. There was a strong backing for the program by the politicians. At the end of 1999, everyone supported it. Weakening of will to implement appeared as we went through 2000. The main issue was the difficulty to 
respond promptly to developments such as speed of decrease in inflation and sharp recovery. Inflation was declining to levels that were never seen in Turkey for a long time. It became politically difficult to keep going as things got better. It wasn't fatigue. It was the impression that they had already won the football match. Although there were people who did say that this was not a $100 \mathrm{~m}$ race but a marathon."

Gazi Ercel, who was the Governor of the Central Bank at the time, asserts that even at the beginning of the program there was not enough commitment on the part of the government. According to him there was, "only half hearted commitment which was galvanized by the prospect of joining the EU. The prime minister for a start did not believe that the program would achieve what he wanted most; growth."

Even after the February 2001 crisis, the political ownership of the program was never complete. The reforms were pushed through by a group of technocrats in the absence of political cohesion. Kemal Dervis observed that, "to what degree a government existed, that could be discussed even."

Undersecretary of the Treasury Oztrak maintained that politicians only owned certain parts of the program and were prepared to blame bureaucrats and the IMF for the other parts.

With the election of the majority AKP government, a stronger political commitment to the IMF program emerged. Bredenkamp argues that improving economic performance also induced further commitment-something that had not happened with the coalition governments. In any case, and according to him, the AKP government knew that a healthy economy was its biggest asset, pointing out that, "the only thing they could do was not mess things up and not allow the economy to deteriorate."

Also in the aftermath of the February 2001 crisis, there was a strong desire countrywide and across all sections of society to take whatever measures were necessary to avoid similar crises again. This provided the government with more political space to implement policy reform than had existed before. As Oztrak observes,

"Everyone was scared of what had happened, and was ready to give in to anyone with a solution. That is why structural reforms were front-loaded to take advantage of the crisis scare, while everyone is on the same side as the pro reform coalition."

\subsection{The Scale and Nature of IMF Support}

While the scale of financial support from the IMF was very modest in the case of the 1999 program, it was much greater in 2001, significantly exceeding quota limits. Cottarelli maintains that the limited resources in 1999 dictated a program that was perhaps over-ambitious in what it set out to achieve, aiming "to bring Turkey out of recession, while trying to eliminate inflation." He argues that it was the lack of severity of the economic situation in 1999, the absence of a pronounced balance of payments problem, combined with the Fund's reluctance to be accused of 'bailing out' the banks that made the Fund unwilling to provide more resources. The stronger financial support in 2001 made the IMF's position more influential, but also created more policy discretion. Both Dervis and Kahkonen attribute the successful 
implementation of the program, in part, to the amount of finance supplied by the Fund.

Of course, another part of the story looks behind the amount of IMF lending. In 1999, many of the IMF's most powerful member countries had become concerned about the size of the Fund's involvement in East Asia in 1997/98. By 2001, and in the aftermath of $9 / 11$, the international political environment had changed radically and worked to the advantage of Turkey in its dealings with the IMF. The US in particular was keen to support a geo-politically important ally. Participants in the programs also agree that in the case of the 2001 program there was 'mutual confidence', which Dervis suggests is the most important ingredient for a successful reform program. He argues that,

"The domestic policy makers must believe that the IMF team is sincerely trying to find the best solutions, is highly competent, and is trying to maximize financial support. And the IMF team must believe that the domestic team is not playing games and will do its best to implement what is agreed."

Akcakoca concurs, asserting that the IMF team was flexible and open to persuasion.

"When teams disagree, if they try to come to a solution by arguing, tension mounts and subjectivity starts to surface. The result is reciprocal stubbornness. There are examples of failed programs in the history for such reasons. During our term, we introduced two technocrat teams to each other, created social space. They saw that the Turkish team wasn't trying to be stubborn, and we saw that they hadn't come to bankrupt our banks. Everyone was there to do their job. We were in the same boat. If the program did not work, everyone's seat was in danger."

\subsection{Initial Conditions}

In principle, the severity of initial conditions prior to the negotiation of an IMF program might work either way. From one point of view, where the problems are less severe there is less to achieve and there is therefore likely to be more success in achieving it. On the other hand, it may require a severe economic crisis to alter entrenched attitudes and to overcome sectional interests. Experience in Turkey is more consistent with the second relationship. The 2001 crisis highlighted the deficiencies of previous policies and created a conducive environment for change. Dervis saw the crisis as motivating the accelerating pace of reform, explaining it as follows.

"The severity and extent of the crisis gave us only two choices, either to implement a program encompassing serious structural transformation and macroeconomic stabilization, or to accept a moratorium. A deep loss of confidence in the government and the entire political system was present. The crisis provided a unique opportunity to push reforms through parliament that otherwise might have taken years to enact. There is an argument against selling the precious political capital all at once and instead to advance step by step, building required coalitions a few at a time. But a severe crisis creates a 
different situation. The need for reform is more urgent and a message of change also needs to be given for markets to respond to."

Other political leaders in Turkey we interviewed, as well as those on the IMF team, agreed with this sentiment. Oral pointed out that while the conditionality included in IMF programs did not change, the crisis unambiguously revealed the need for the policies to be carried through. Kahkonen claims that good use was made of the opportunity for reform and Bredenkamp identifies a virtuous circle as economic recovery allowed the AKP government to show that the policies were working; this re-enforced their commitment to continued economic reform.

\subsection{Other Factors: Europe and Influential Technocrats (the Dervis Effect)}

Those interviewed by us pointed to two other factors as assisting the implementation of IMF programs in Turkey. The first was the longer term objective of joining the European Union and the perception that this was attainable. This provided a further incentive to pursue economic policies that were deemed to be sound and consistent with those of EU members. These included disciplined fiscal policy as well as structural reform. The satisfactory implementation of IMF programs was seen by some as a prerequisite for eventual EU membership. The 2001 crisis also enhanced the desire to join the EU and therefore indirectly created greater impetus for reform.

Finally there is little doubt that Kemal Dervis was instrumental in orchestrating the implementation of the IMF programs in which he was involved. With experience of the Washington-based international financial institutions, he was in a strong position to act as a mediator. He carried the confidence of both the domestic policy makers and the IMF and was therefore able to extract the most from each of them. The IMF viewed him as "not your usual politician" and as being able to deliver on policy reform. Dervis describes his role in the following way.

"There was a pro-reform bureaucracy already in existence and they were waiting for all these reforms. My contribution was to bring them together as a coherent whole. I haven't invented any of them on my own. I was making sure the reforms were consistent, and their timings were right. One of my jobs was to convince politicians on the necessity of implementing reforms. My other function was resource mobilization, to find the necessary financing needs of the country during the crisis."

\section{Discussion and Policy Implications}

In an attempt to offer some quantification of what is qualitative evidence, we analyzed the frequency with which particular factors were mentioned by those we interviewed (see Table 4 and Fig. 1). The structured interviews were designed to reflect the determinants of program implementation that have been suggested by the literature. The relative significance of the variables was determined according to the number of times each variable was cited by participants. We did not distinguish between whether the interviewee was a domestic politician, or an official, or a member of IMF staff while quantifying our results (though we offer an analysis of 


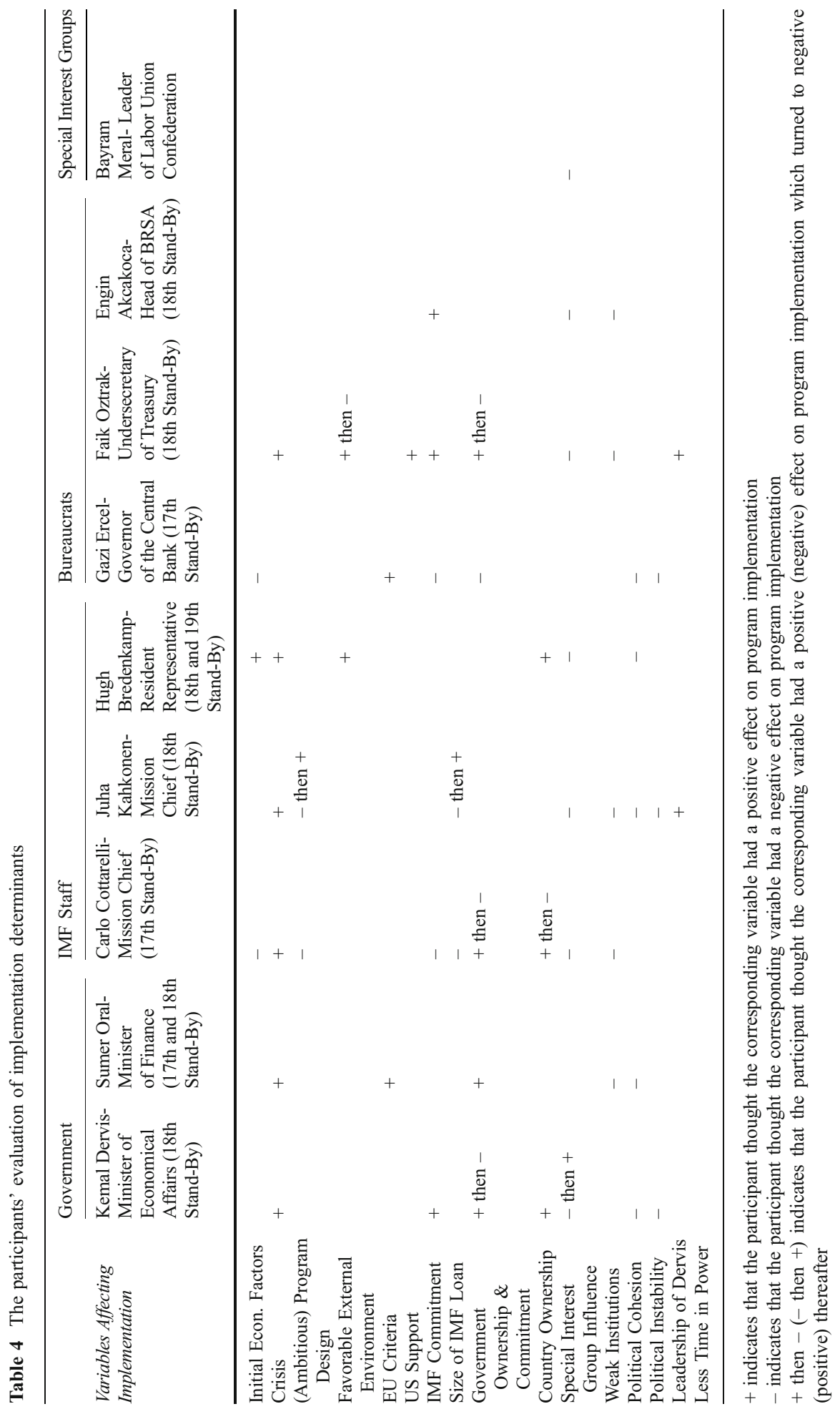




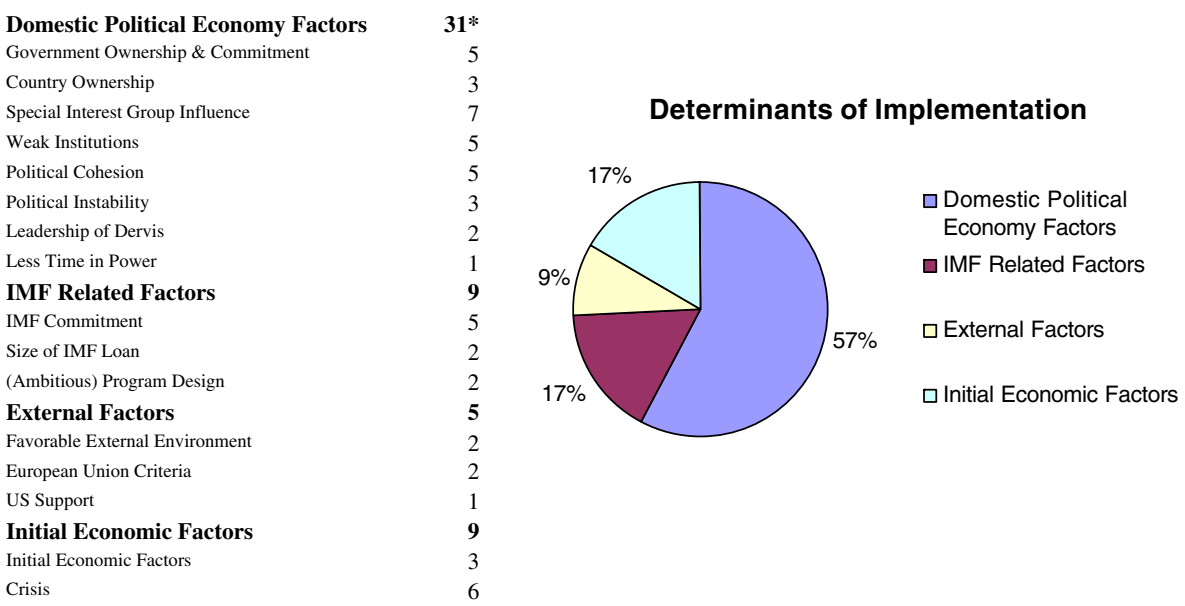

Fig. 1 Distribution of factors affecting the implementation of IMF programs in Turkey. ${ }^{*}$ Number of times each variable has been cited by participants

their responses according to their affiliation below). It may therefore be that our sample is biased in some way. We did, however, try to ensure a reasonably representative spread across all participants involved in the programs. We divided the influences over implementation into four categories, again drawing on the extant literature. These were: domestic political economy factors, IMF related factors, external factors and initial conditions. But we also sub-divided each category into more specific determinants as shown in Fig. 1.

Judging by the number of times each variable was referred to, domestic political economy factors were perceived as dominating program implementation. Such factors were perceived as more important than IMF-related factors, external factors and initial economic factors combined. Within the domestic political economy factors, the influence of interest groups was the most commonly mentioned variable influencing program implementation. Government ownership, institutions and political cohesion were, however, also often perceived as being important determinants of implementation (see Fig. 1).

The results can be interpreted in various ways. Firstly, it may be seen from Table 4 that the significance of some variables differs between the 1999 and 2002 programs. While initial economic factors and program design mattered in the 17th Stand-By, US support, a favorable global environment and IMF commitment seem to have been important in the case of the 18th Stand-By. Meanwhile, factors such as EU criteria, interest groups and government ownership are important in both episodes. The distinct difference between two consecutive programs in one country is testament to the need for a subtle and nuanced approach to program implementation.

Secondly, an interesting picture emerges when we group the participants' responses by their affiliation. The bureaucrats' and the IMF staff's views on why programs succeed or fail seem to be reasonably aligned with each other, while the politicians and the representatives of interest groups seem to share views that differ from those of the bureaucrats and IMF staff. For example, Finance Minister Sumer Oral did not accept the weakening of the government's ownership, or the impact of vested interests as a reason for slippage in implementation. Bayram Meral, leader of the labour union 
confederation, saw the influence of interest groups as being important, but pointed towards corruption and powerful business lobbies, rather than labour unions.

While our results suggest that the influence of special interest groups, a lack of domestic ownership, a lack of political cohesion and weak institutions were seen as the most significant factors exerting a negative effect on program implementation, it may be noted that these factors are likely to be positively related to one another. The influence of interest groups may, for example, be expected to be greater where a government lacks cohesion and is uncommitted to the program. Where the government is stronger and more committed to it, special interest groups will be in a weaker position to exert influence.

Our findings also suggest that the IMF can influence implementation by its own actions and commitment, by not being excessively ambitious in terms of what it sets out to achieve, as well as by providing sufficient resources to make any preferred program feasible. Again, some of these factors will be related to the domestic political economy situation. For example, limited financial support will place a greater weight on economic adjustment and this may in turn mean that certain policies have to be included in the program in spite of it being accepted that they will encounter strong domestic political resistance. Moreover, IMF commitment in terms of resources may imply a willingness to be flexible and to make compromises.

External factors were generally seen as being less significant than those associated with domestic political economy. But, once more, there could be interaction between them, with, for example, the desire to join the EU making the government more committed to reform than it would otherwise have been, and the global political situation affecting the willingness of the US to offer support via the intermediation of the IMF.

In terms of initial conditions, there was a strong perception that the severe economic crisis in 2001 enhanced the willingness across society to implement a program of economic reform that would reduce the probability of future crises. However, the relationship between initial economic conditions and implementation may be more subtle than this suggests. Up to a point, it may be that deteriorating economic circumstances make it more difficult to implement a program of reform, because there is more to achieve. This will be particularly the case if there is no significant increase in the commitment to reform. However, when the deterioration is sufficiently great to be classified as a crisis, it may be that the increase in the commitment to reform outweighs the additional challenges that the crisis creates. After a crisis has passed, two responses are possible, with these being contingent on other factors. With a weak coalition government exhibiting evaporating ownership, sectional interests may re-establish themselves in an attempt to derive greater direct benefit from the economic recovery. By contrast with a strong government committed to maintain the momentum of reform, economic recovery may provide the justification for not reneging on policies. Both these responses to IMF programs have been observed in Turkey.

Our interpretation of the qualitative evidence provided by our series of interviews is that the implementation of IMF programs depends on contingent combinations of factors in quite complex ways that are likely to change over time. They may even be endogenous to the implementation and effects of the programs. Methodologically, large sample regression analysis may identify relevant factors, broadly defined, but will not capture the complexities and idiosyncrasies.

Our findings in Turkey are consistent with the large sample results but they also illustrate the complexities and nuances that are not picked up at the higher level of aggregation. 
However, to what extent are our findings in Turkey applicable to other countries? To test this we briefly examined six other case studies that our econometric analysis in Arpac et al. (2008) identified as outliers in terms of the interruption of IMF programs; Kyrgyzstan, Jordan, Guyana, the Democratic Republic of Congo, Indonesia and the Philippines.

In the interests of brevity, we do not report our full findings for each of these cases. However, they broadly confirm the findings of our Turkey case study. In particular, they reveal the importance of powerful special interest groups opposed to specific structural reforms and political fragmentation and instability in contributing to the interruption of programs. The precise nature of these factors varies between countries, but in general terms, they seem to be universally important.

These general messages carry implications for the design of IMF programs. First, programs need to move beyond technical economics. The political environment in which domestic policy is carried out needs to be taken into account. This could involve contingency planning. The science of economics needs to be combined with the art of the possible. Second, the Fund also needs to move beyond the loose and ill-defined concept of 'ownership' in assessing the chances for implementation. It needs to be fully informed of specific domestic political and institutional realities. But it also needs to exploit what scope there is for using conditionality as a way of supporting economic reform and institutional change. It needs to exploit any scope that may exist for strengthening national ownership. The opportunities for such influence may change through time and the Fund needs to take chances as and when they present themselves. Moreover, the Fund needs to acknowledge that some conditions will be politically easier to implement than others. Third, the nature of the relationship between governments, national officials and the IMF needs to be one of trust, confidence and flexibility. An institutional mechanism for seeking to replicate the 'Dervis effect' identified in Turkey needs to be considered. This could involve giving an enhanced role to the IMF's Resident Representatives, reducing the mobility of mission chiefs or ensuring continuity in other ways, and encouraging country officials to spend time on secondment at the Fund.

\section{Concluding Remarks}

Since the early 2000s, increased attention has been paid to the implementation of IMF programs. There has been research into the theory that lays behind it as well as large sample regression analyses that have attempted to isolate its principal determinants. However, as a methodological approach, regression analysis is constrained by the availability of data. It will provide a broad rather than a detailed picture. The complexities and nuances of implementation will be better revealed by case studies, although the danger from these is that the degree of detail may obscure the underlying messages. For this reason, the different methodologies need to be pursued in tandem and to be seen as complementary rather than competitive.

Informed by the theoretical work and the results of available regression analyses this paper has examined Turkey as a case study of the implementation of IMF programs. The existing theoretical and empirical research allows a number of ideas or hypotheses to be formulated that then help to structure the case study. Apart from our own interpretation of events, our approach has been to conduct a series of 
interviews with those involved, including politicians, bureaucrats, representatives of special interests and IMF personnel. From these interviews we have sought to extract broad areas of consensus about the determinants of implementation.

We discover a reassuring consistency between the theory of implementation, the results of large sample regression analysis and our case study findings. The theory has stressed the relevance of ownership and the role of special interest groups. The regression analyses have also emphasized issues of domestic political economy. In the case of Turkey we are able to offer greater precision about how these factors worked in detail and in practice. We are able to identify factors that are widely perceived as being important. These include not only a range of domestic political economy factors, but also the nature of IMF commitment and the existence of a crisis. We point out, however, that these factors interact. Any complete explanation of implementation is therefore likely to be a contingent one. We check whether our findings are broadly generalizable not only by comparing them against the large sample regression results achieved by us and by others but also by undertaking a brief examination of other case studies (reported in Arpac et al. 2008).

The message that emerges is that we can be reasonably confident about the broad categories of factors that affect the implementation of IMF programs. The relative importance of these factors and the way in which they present themselves will, however, vary from case to case. In designing programs that stand the best chance of being implemented the IMF needs to be mindful of these factors and to address them. We explore various ways of bringing this about. Although these may involve significant institutional change for the Fund, the reward should be an improved record of implementation and a strengthened perception of the IMF's relevance and effectiveness.

\section{Appendix A: List of Interview Participants}

Kemal Dervis- Head of the United Nations Development Programme, Former Economy Minister of Turkey, 2001-2002. 30 min meeting on 16 February 2006, in New York City.

Faik Oztrak- Former Undersecretary of Turkish Treasury, 2001-2002. $40 \mathrm{~min}$ meeting on 13 September 2005, in Ankara.

Gazi Ercel- Former Governor of Central Bank of Turkey, 1996-2001. 80 min meeting on 28 October 2005, in Istanbul.

Sumer Oral- Former Finance Minister of Turkey, 1999-2002. 120 min meeting on 14 April 2006, in Ankara.

Engin Akcakoca- Former Head of Banking Regulation and Supervision Agency of Turkey, 2001-2003. 30 min meeting on 20 April 2006, in Washington D.C.

Bayram Meral- Member of Turkish Parliament, 2002 to date, Former Secretarygeneral of the Turkish Confederation of Labor Unions, 1992-2002. 100 min meeting on 13 April 2006, in Ankara.

Juha Kahkonen- Former Mission Chief of IMF to Turkey, 2001-2003. $40 \mathrm{~min}$ meeting on 22 February 2006, in Washington D.C.

Carlo Cottarelli- Former Mission Chief of IMF to Turkey, 1999-2001. $50 \mathrm{~min}$ meeting on 23 February 2006, in Washington D.C. 
Hugh Bredenkamp- Senior Resident Representative of IMF to Turkey, 2002 to date, 90 min meeting on 13 April 2006, in Ankara.

David Goldsbrough- Former Deputy Director of the Independent Evaluation Office of the IMF, 2001-2006. 40 min meeting on 21 February 2006, in Washington D.C.

Marcelo Selowsky- Assistant Director of the Independent Evaluation Office of the IMF, 2001 to date. 50 min meeting on 21 February 2006, in Washington D.C.

Note: In addition to above interviewees, academics Professor Ziya Onis, Nazif Ekzen and Senior Tax Auditor of Turkey Ministry of Finance, Ahmet Veysel Ozer provided their valuable comments.

\section{Appendix B: Timeline of Events: 1999-2004}

Table 5 Timeline of Events: 1999-2004

18 April 1999

10 December 1999

19 December 1999

10 April 2000

22 June 2000

31 August 2000

20 November 2000

06 December 2000

30 January 2001

19 February 2001

23 February 2001

02 March 2001

15 May 2001

03 May 2001

31 March 2001

26 June 2001

17 July 2001

31 July 2001

20 November 2001

18 January 2002

03 April 2002

19 June 2002

30 July 2002

10 August 2002

End August 2002

03 November 2002
Parliamentary Elections held. Coalition government of Democratic Left Party (DSP), Nationalist Action Party (MHP) and Motherland Party (ANAP) came to power.

Turkey's candidacy for full membership was endorsed at the Helsinki Summit of European Union

A three year Stand-By Program agreed with the IMF (17th Stand-By

Agreement of Turkey)

First Review of the 17th Stand-By completed

Second Review of the 17th Stand-By completed

The Banking Supervision and Regulation Agency became operational

Banking crisis started

The Supplemental Reserve Facility of the IMF was granted, and capital outflow stopped. Third and Fourth Reviews of the 17th Stand-By completed

Fifth Review of the 17th Stand-By completed

Public dispute between President Sezer and Prime Minister Ecevit.

The short term interest rates rocketed to over 5,000\%

The exchange rate based stabilization program failed, the lira left to float

Dervis appointed as the Minister of Economic Affairs

"Strong Economy Program" announced by Dervis

Sixth and Seventh Review of the 17th Stand-By completed

State Minister Yuksel Yalova resigned over disagreements over Tobacco Law

Eighth Review of the 17th Stand-By completed

Minister Enis Oksuz resigned over disputes on Telekom privatization

Ninth Review of the 17th Stand-By completed

Tenth and last review of the 17th Stand-By completed

New three-year Stand-By agreement with the IMF signed (18th Stand-By agreement of Turkey)

First Review of the 18th Stand-By completed

Second Review of the 18th Stand-By completed

Third Review of the 18th Stand-By completed

Kemal Dervis resigned from the government

The legislation of financial sector reform, agricultural reform, and privatization accomplished, satisfying both IMF conditionality and EU's Copenhagen criteria

Parliamentary elections, the AKP majority government came to power and declared they would continue implementing the Stand-By program 
12-13 December 2002 Copenhagen Summit of the European Union where the decision to start accession talks with Turkey was taken, on the condition that Turkey meets all the Copenhagen criteria by December 2004

05 April 2003

Fourth Review of the 18th Stand-By completed

09 April 2003

Parliament passed first phase of direct tax reform into law, in line with program's performance criterion

25 July 2003

31 October 2003

Fifth Review of the 18th Stand-By completed

Turk Telekom privatization plan target missed for the third time (Program benchmark, previous targets: April 2002, end-November 2002). Sixth Review of the 18th Stand-By completed

02 April 2004

Parliament approved the second phase of direct tax reform completing a prior action for the seventh review. Seventh Review of the 18th Stand-By completed

15 July $2004 \quad$ Eighth and last review of the 18th Stand-By completed

\section{References}

Alper, E. (2001). The Turkish liquidity crisis of 2000: what went wrong? Russian and East European Finance and Trade, 10(37), 51-71.

Akyuz, Y., \& Boratav, K. (2003). The making of the Turkish crisis. World Development, 31(9), 15491566.

Arpac, O., Bird, G., \& Mandilaras, A. (2008). Stop interrupting: an empirical analysis of the implementation of IMF programs. World Development, 36(9), 1493-1513.

Boratav, K. (2003). Turkiye Iktisat Tarihi, 1908-2005. Istanbul: Imge Kitabevi Yayinlari.

Cizre, U., \& Yeldan, E. (2005). The Turkish encounter with neo-liberalism: economics and politics in the 2000/2001 crises. Review of International Political Economy, 12(3), 387-408.

Dervis, K. (2005). Returning from the Brink: Turkey's efforts at systemic change and structural reform. In T. Besley, \& R. Zagha (Eds.), Development challenges in the 1990s (pp. 81-102). New York: Oxford University Press.

Drazen, A. (2002). Conditionality and ownership in IMF lending: a political economy approach. IMF Staff Papers (special issue), 49, 36-67.

Dreher, A. (2003). The influence of elections on IMF program interruptions. Journal of Development Studies, 39(6), 101-120.

Edwards, S. (1989). The international monetary fund and the developing countries: a critical evaluation. In Carnegie-Rochester Conference Series on Public Policy. IMF Policy Advice, Market Volatility, Commodity Price Rules and Other Essays (pp.7-68). North Holland.

Egilmez, M. (2005). IMF ile Iliskiler. Radikal (Turkish Daily), October, 21, 2005

Ekzen, N. (1980). 1948, 1958 ve 1970 Devaluasyonlari. Mimeo: Ankara.

Grossman, G. M., \& Helpman, E. (2001). Special interest politics. Massachusetts: The MIT.

IMF Staff Reports on Turkey, 2000-2004.

Ivanova, A., Mayer W., Mourmouras A., \& Anayiotas, G. (2003). What determines the success or failure of fund-supported programs? IMF Working Paper, 3(8), Washington, DC.

Joyce, J. P. (2006). Promises made, promises broken: a model of IMF program implementation. Economics \& Politics, 18(3), 339-365.

Khan, M. S., \& Sharma, S. (2000). IMF conditionality and country ownership of programs. IMF Working Paper, 142: Washington, DC.

Killick, T. (1995). IMF programs in developing countries: Design and impact. New York: Routledge.

Mayer, W., \& Mourmouras, A. (2004). IMF conditionality and the theory of special interest politics. Comparative Economic Studies, 46(3), 400-22.

Mayer, W., \& Mourmouras, A. (2008). IMF conditionality: an approach based on the theory of special interest politics. Review of International Organizations, 3(2), 105-121.

Mecagni, M. (1999). The causes of program interruptions. In H. Bredenkamp, \& S. Schadler (Eds.), Economic adjustment and reform in low-income countries (pp. 215-276). Washington, DC: IMF.

Nsouli, S., Atoian, R., \& Mourmouras, A. (2004). Institutions, program implementation, and macroeconomic performance. IMF Working Paper, 04/184. 
Onis, Z. (1986). Stabilization and growth in a semi-industrial economy: an evaluation of the recent Turkish experiment 1977-1984. METU Studies in Development, 13, 7-18.

Onis, Z., \& Ozmucur, S. (1988). The role of the financial system in the creation and resolution of macroeconomic crises in Turkey. Istanbul: Department of Economics, Bogazici University.

Onis, Z., \& Rubin, B. (2003). The Turkish economy in crisis. London: Frank Cass.

Pritchett, L. (1996). Measuring outward orientation in LDCs: Can it be done? Journal of Development Economics, 49, 307-335.

Polak, J. J. (1991). The changing nature of IMF conditionality. Essays in International Finance, 184. Princeton: International Finance Section, Department of Economics.

Tsebelis, G. (2001a). Veto players: How political institutions work. Princeton, NJ: Princeton University Press.

Tsebelis, G. (2001b). Veto players and institutional analysis. UCLA: Mimeo, Department of Political Science.

Yeldan, E. (2001). Kureselllesme Surecinde Turkiye Ekonomisi: Bolusum, Birikim ve Buyume. Istanbul: Iletisim Yayinlari. 